\title{
Ocular Findings and Multimodal Imaging Characteristics of Retinitis Pigmentosa Patients
}

\section{Retinitis Pigmentosa Hastalarının Oküler Bulguları ve Multimodal Görüntüleme Özellikleri}

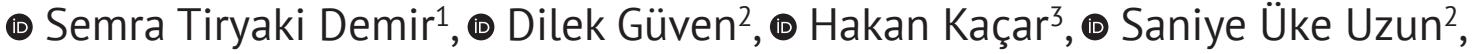 \\ (-) Murat Karapapak ${ }^{4}$ \\ ${ }^{1}$ University of Health Sciences Turkey, Prof. Dr. Cemil Taşcıoğlu City Hospital, Clinic of Ophthalmology, Istanbul, Turkey \\ ${ }^{2}$ University of Health Sciences Turkey, Şişli Hamidiye Etfal Training and Research Hospital, Clinic of Ophthalmology, Istanbul, Turkey \\ ${ }_{3}^{3}$ Şanlıurfa Viranşehir State Hospital, Clinic of Ophthalmology, Şanlıurfa, Turkey \\ ${ }^{4}$ University of Health Sciences Turkey, Başakşehir Çam and Sakura City Hospital, Clinic of Ophthalmology, Istanbul, Turkey
}

Background: To investigate the ocular findings and multimodal imaging characteristics of retinitis pigmentosa (RP) patients.

Materials and Methods: Patients who were followed up in our clinic for RP were evaluated retrospectively between June 2014 and July 2017. Ophthalmological examination included best corrected visual acuity (BCVA), biomicroscopy, fundoscopy, and axial length (AL) measurements. Optical coherence tomography (OCT) and fundus autofluorescence (FAF) imaging properties of macular region were examined in detail.

Results: In the study, 865 eyes of 446 RP patients were evaluated. In biomicroscopic examination, cataract surgery was performed in $23.6 \%$ of the eyes, and $29.1 \%$ of the eyes had posterior subcapsular cataract. In fundus examination, end-stage RP was detected in $67.4 \%$ of the eyes and severe macular atrophy in $9.8 \%$ of the eyes. The mean AL was $23 \pm 1.8 \mathrm{~mm}$, the mean central macular thickness (CMT) was $136.6 \pm 87.1 \mathrm{um}$, and the mean subfoveal choroidal thickness (SCT) was $178.3 \pm 89.1 \mathrm{um}$. There was a positive correlation between BCVA and CMT, SCT, external limiting membrane and ellipsoid zone line integrity $(p<0.001)$. Inner limiting membrane thickening and/or epiretinal membrane $47.7 \%$, intraretinal hyperreflective foci $43.1 \%$, micropseudocyst $15.8 \%$ and cystoid macular edema $6.5 \%$ were among the most commonly seen macular abnormalities detected in OCT. There was presence of a hyper-autofluorescent (AF) ring in $28.4 \%$, abnormal hyper-AF patterns at the macula in $45.3 \%$. There was a positive correlation between external limiting membrane-ellipsoid zone line integrity and the hyper-AF ring $(\mathrm{p}<0.001)$.

Conclusion: Screening RP patients using OCT, FAF and biometry findings may be useful both for documenting of the disease and for selecting candidates for innovative treatment modalities like retinal prosthesis, stem cell therapy.

Keywords: Fundus autofluorescence, optical biometry, optical coherence tomography, retinal dystrophy

Amaç: Retinitis pigmentosa (RP) hastalarının oküler bulgularını ve multimodal görüntüleme özelliklerini araştırmak.

Gereç ve Yöntemler: Kliniğimizde RP nedeniyle takip edilen hastalar Haziran 2014 ve Temmuz 2017 tarihleri arasında retrospektif olarak değerlendirildi. Oftalmolojik muayenede en iyi düzeltilmiş görme keskinliği (EIDGK), biyomikroskopi, fundoskopi, aksiyel uzunluk (AL) ölçümleri yapıldı. Maküla bölgesinin optik koherens tomografi (OKT) ve fundus otofloresans (FOF) görüntüleme özellikleri ayrıntılı olarak incelendi.

Bulgular: Çalışmada 446 RP hastasının 865 gözü değerlendirildi. Biyomikroskopik muayenede; gözlerin \%23,6'sına katarakt ameliyatı yapılmıştı,\%29,1'inde arka subkapsüler katarakt mevcuttu. Fundus muayenesinde; gözlerin \%67,4'ünde son dönem RPve

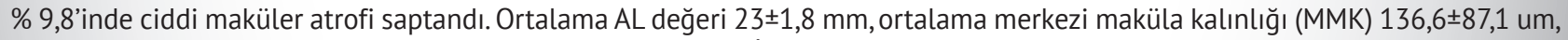
ortalama subfoveal koroid kalınlığı (SKK) 178,3ะ89,1 um idi. EIDGK ile MMK, SKK, external limitan membran ve elipsoid zon hattı

Address for Correspondence: Semra Tiryaki Demir, University of Health Sciences Turkey, Prof. Dr. Cemil Taşcloğlu City Hospital, Clinic of Ophthalmology, İstanbul, Turkey Phone: +90 2123145555 E-mail: dr-semra@hotmail.com ORCID ID: orcid.org/0000-0002-5453-6041

Received: 01.12.2020 Accepted: 19.02.2021 
bütünlüğü arasında anlamlı pozitif korelasyon mevcuttu ( $p<0,001)$. OKT'de saptanan en sık görülen makula patolojileri sırasıyla; iç limitan membran kalınlaşması ve/veya epiretinal membran \%47,7, retina içinde hiperreflektif odaklar, \%43,1, mikropseudokist \%15,8 ve kistoid maküla ödemi \%6,5 idi. FOF görüntülemede; gözlerin \%28,4'ünde hiper-otofloresan halka, \%45,3’ünde makulada anormal hiper otofloresans paternler mevcuttu. External limitan membran ve elipsoid zon hattı bütünlüğü ile hiper-otofloresan halka varlığı arasında pozitif korelasyon saptandı $(p<0,001)$.

Sonuç: RP hastalarının OKT, FOF ve biyometri bulguları kullanılarak taranması, hem hastalığın belgelenmesi hem de retina protezi, kök hücre tedavisi gibi yenilikçi tedavi modaliteleri için adayların belirlenmesinde faydalı olabilir.

Anahtar Kelimeler: Fundus otofloresans, optik biyometri, optik koherens tomografi, retina distrofisi

\section{Introduction}

Retinitis pigmentosa (RP) encompasses a group of inherited retinal dystrophies characterized by primary degeneration of rod and cone photoreceptors and is a leading cause of visual disability, affecting more than 1.5 million patients worldwide (1).

Morphological and functional assessment of photoreceptors in the macula can be useful in estimating residual retinal function in RP patients. Optical coherence tomography (OCT) is a well-established method of examining retinal and choroidal architecture in situ. It allows the evaluation of retinal and choroidal changes of RP at presentation and during the follow-up period $(2,3,4)$. Fundus autofluorescence (FAF) results from the accumulation of lipofuscin in retinal pigment epithelium (RPE) cells and has been used to investigate RPE and retinal function. Several FAF patterns have been observed in patients with RP (2).

In this study, the clinical and multimodal imaging findings of 446 RP patients were evaluated by using biometry, OCT and FAF. Therefore, we aimed to report our findings to contribute to the literature in terms of presenting quantitative data in Turkey.

\section{Material and Methods}

Patient charts and medical records were reviewed retrospectively between June 2014 and July 2017. Nonsyndromic RP cases were evaluated. This study was approved by the local human research ethics committee, in accordance with the Declaration of Helsinki, and written informed consent was obtained from all participants.

Age, gender, past cataract or other ophthalmic surgeries and presence of additional eye disease were recorded in the patients' personal histories. Parental consanguinity was recorded in the family history. Genetic analysis was not performed in terms of hereditary transmission.

Eye position in primary gaze, presence of strabismus and nystagmus, best corrected visual acuity (BCVA), biomicroscopy and fundus were evaluated. The BCVA was recorded using the
Snellen chart. Tropicamide $1 \%$ eye drops were used for pupil dilatation and lens clarity was assessed by biomicroscopy. The state of the lens was grouped as clear lens, pseudophakia, posterior subcapsular cataract (PSC), nuclear-nucleocortical cataract and aphakic.

The degree of retinopathy was assessed with fundoscopy and classified as early stage (bone spicule-like pigment changes in the equatorial region, macula and optical disc unaffected), late stage (widespread chorioretinal atrophy, loss of foveal reflex in the macula, waxy pallor of the disc), severe macular atrophy, sectorial RP and RP sine pigmento. Optical biometry (AL-Scan, Nidek Co., Aichi, Japan) was used for measuring axial length (AL).

A high resolution spectral-domain OCT (3D-OCT 2.000, Topcon Corp., Tokyo, Japan) device was used for detailed evaluation of the macula area and FAF imaging. The " 6 $\mathrm{mm}$ 3D mode and $9 \mathrm{~mm}$ line mode" technique was used for macula imaging, the "9 $\mathrm{mm}$ line mode" enhanced depth imaging technique was used for subfoveal choroid imaging. The values of central macula thickness (CMT) and subfoveal choroidal thickness (SCT) were recorded between 12.00 and 14.00 oclock in the afternoon. The CMT was measured from the foveola, so that the inner border would be the inner limiting membrane (ILM) and the outer border would be the RPE. The SCT was measured manually at 500 microns interval from the fovea, so that the inner border would be the RPE and the outer border would be the sclera (5). SCT less than 250 microns was evaluated as choroidal thinning. The presence of choroidal symmetry between both eyes was also recorded.

The macular area was examined in 3 groups with OCT as outer retinal, intraretinal and vitreomacular interface abnormalities. Outer retina abnormalities were evaluated in detail as loss of external limiting membrane (ELM) line integrity and loss of ellipsoid zone (EZ) line integrity. The loss of EZ and ELM line integrity was classified as total loss and partial loss (partially preserved in subfoveal area). Intraretinal abnormalities were evaluated in detail as micropseudocyst (MPC), cystoid macular edema (CME), subretinal fluid and presence of intraretinal hyperreflective foci (HF). Vitreomacular interface abnormalities were evaluated in 
detail as ILM thickening (ILMT), epiretinal membrane (ERM), combination of ILMT and ERM, presence of vitreous bands, full thickness macular hole (FTMH) and lamellar macular hole (LMH).

FAF imaging was evaluated under the headings of FAF symmetry between both eyes, presence of hyper-AF ring, abnormal hyper-AF patterns at the macula with irregular distribution, absence of $\mathrm{AF}$ and decreased $\mathrm{AF}$ at the periphery (5). In case of media opacities, nystagmus, low patient cooperation FAF, OCT or biometry were not evaluated.

\section{Statistical Analysis}

SPSS 22.0 for Windows software was used for statistical analysis. Descriptive statistics were given as number and percentage for categorical variables and as mean, standard deviation, minimum, maximum, and median for numerical variables. When the numerical variables met the conditions of the normal distribution, the Student's t-test was used to compare the two independent groups and the MannWhitney $U$ test was used when the normal distribution conditions were not met. Since the relationships between numerical variables did not meet the condition of a parametric test, they were analyzed using the Spearman Correlation Analysis. Statistical significance level of alpha was accepted as $\mathrm{p}<0.05$.

\section{Results}

Demographic Findings: Eight hundred seventy-five eyes of 446 RP patients were evaluated. The mean age was $43.5 \pm 14.9$ (6.5-82) years, 173 patients were (38.8\%) female, 273 patients (61.2\%) were male. The parental consanguinity rate was $56.4 \%$. According to the expression of the patients, the mean age of nyctalopia was $15.8 \pm 12.3$ years, the mean age of onset of central vision loss was $22.8 \pm 12.6$ years, and the mean age of severe central blindness was $34.6 \pm 15$ years.

Additional Eye Diseases: There was no additional ocular pathology in 639 eyes (71.6\%). The most common additional eye diseases were myopia in 134 eyes (15\%), glaucoma in 45 eyes (5\%), hypermetropia in 26 eyes (2.9\%) and corneal opacity in 15 eyes (1.6\%). Nystagmus was seen in 88 (23.4\%), orthophoria in 212 (57\%), exotropia in 148 (39.8\%), esotropia in $7(1.9 \%)$ and vertical strabismus in $5(1.3 \%)$ of the patients. As the BCVA decreased, the frequency of strabismus and nystagmus was found to be significantly higher $(p<0.001)$.

Best Corrected Visual Acuity: Categories and corresponding percentages were: no light perception in 56 (6.4\%), only light perception in 257 (29.4\%), seeing hand movements in 254 (29\%), counting fingers at 1 meter at 10/100 in 127 (14.5\%) and $\geqslant 10 / 100$ in 181 (20.7\%) of the eyes.

Fundus Findings: Fundus examination revealed earlystage RP in 139 (16.4\%), end-stage RP in 570 (67.4\%), severe macular atrophy in 83 (9.8\%), RP sine pigmento in 13 (1.5\%) and sectorial RP in $2(0.2 \%)$ of the eyes.

Lens Findings: Two hundred eleven (23.6\%) eyes were pseudophakic and 14 eyes (1.6\%) were aphakic. Biomicroscopic examination revealed clear lens in 326 (37.7\%), PSC in 252 (29.1\%) and senile nuclear-nucleocortical cataract in $69(8 \%)$ of the eyes. The BCVA of the eyes with PSC and nuclear cataract were less than eyes with clear lens and pseudophakic $(p<0.001)$. The mean CMT was $134.2 \pm 92$ um in eyes that had undergone cataract surgery and $136.4 \pm 76 \mathrm{um}$ in the others $(p=0.194)$.

Axial Length: The mean AL was $23 \pm 1.8$ (17-42.2) mm. There was no difference in AL between right and left eyes $(p=0.082)$. There was no correlation between AL and age, CMT and SCT ( $p$ values of $0.085,0.669,0.073$, respectively).

Macula OCT Imaging Findings: The macular area could be evaluated in 633 of the eyes (79.4\%) with OCT. The distribution of OCT imaging findings of patients with RP is shown in Table 1. Macula OCT images of some of our cases are shown in Figure 1. The mean CMT was $136.6 \pm 87.1$ (2-839) um. There was no significant difference in CMT between right and left eyes $(p=0.626)$. There was a significant negative correlation between age and CMT $(p<0.001)$, and no difference between gender and CMT $(p=0.559)$.

\begin{tabular}{|c|c|c|}
\hline & $\begin{array}{l}\text { Optical } \\
\text { coherence } \\
\text { tomography } \\
\text { imaging findings }\end{array}$ & $\begin{array}{l}\text { Eyes } \\
\text { (n) \% }\end{array}$ \\
\hline ILMT & 186 & 28.2 \\
\hline ERM & 108 & 16.3 \\
\hline ILMT and ERM & 21 & 3.2 \\
\hline Vitreous bands & 16 & 2.4 \\
\hline MPC & 100 & 15.8 \\
\hline CME & 41 & 6.5 \\
\hline Subretinal fluid & 11 & 1.7 \\
\hline LMH & 10 & 1.5 \\
\hline FTMH & 6 & 0.9 \\
\hline Intraretinal HF & 290 & 43.1 \\
\hline Total loss of ELM line integrity & 402 & 60.4 \\
\hline Partial loss of ELM line integrity & 224 & 33.7 \\
\hline Total loss of EZ line integrity & 396 & 58.2 \\
\hline Partial loss of EZ line integrity & 235 & 34.4 \\
\hline \multicolumn{3}{|c|}{$\begin{array}{l}\text { ILMT: Inner limiting membrane thickening, ERM: Epiretinal membrane, MPC: } \\
\text { Micropseudocyst, CME: Cystoid macular edema, LMH: Lamellar macular hole, } \\
\text { FTMH: Full thickness macular hole, HF: Hyperreflective foci, ELM: External } \\
\text { limiting membrane, EZ: Ellipsoid zone }\end{array}$} \\
\hline
\end{tabular}


There was a positive correlation between BCVA and CMT, $E L M$ and EZ line integrity $(p<0.001)$. Vitreomacular interface anomalies were seen more often in patients who underwent cataract surgeries, had less BCVA and were elderly ( $p$ values of $<0.001,0.006,<0.001$, respectively). A significant positive correlation was found between CMT and subretinal fluid, vitreomacular interface anomalies, and CME ( $p$ values of $0.012,<0.001,<0.001$, respectively). There was a significant positive correlation between CMT and ELM and EZ line integrity $(p<0.001)$ and a significant negative correlation between the CMT and intraretinal HF $(p<0.001)$.

Choroidal OCT Imaging Findings: The mean SCT was $178.3 \pm 89.1(2-441) \mu \mathrm{m}$. SCT thinning was observed in 521 (77.4\%) of the eyes. Choroid findings were asymmetry between two eyes in 39 (12.3\%) of patients. As patients were older, SCT thinning was greater $(p<0.001)$. There was a significant positive correlation between BCVA and SCT $(p<0.001)$. The mean SCT was $132.5 \pm 93 \mu \mathrm{m}$ in eyes with no light perception, $157 \pm 88 \mu \mathrm{m}$ in eyes with only light perception, $169.3 \pm 95 \mu \mathrm{m}$ in eyes with seeing hand movements, $191.2 \pm 85 \mu \mathrm{m}$ in eyes with counting fingers at 1 meter at 10/100 and 214.0 \pm 71 um in eyes with $\geqslant 10 / 100$. There was a significant positive correlation between SCT and CMT ( $p<0.001)$.

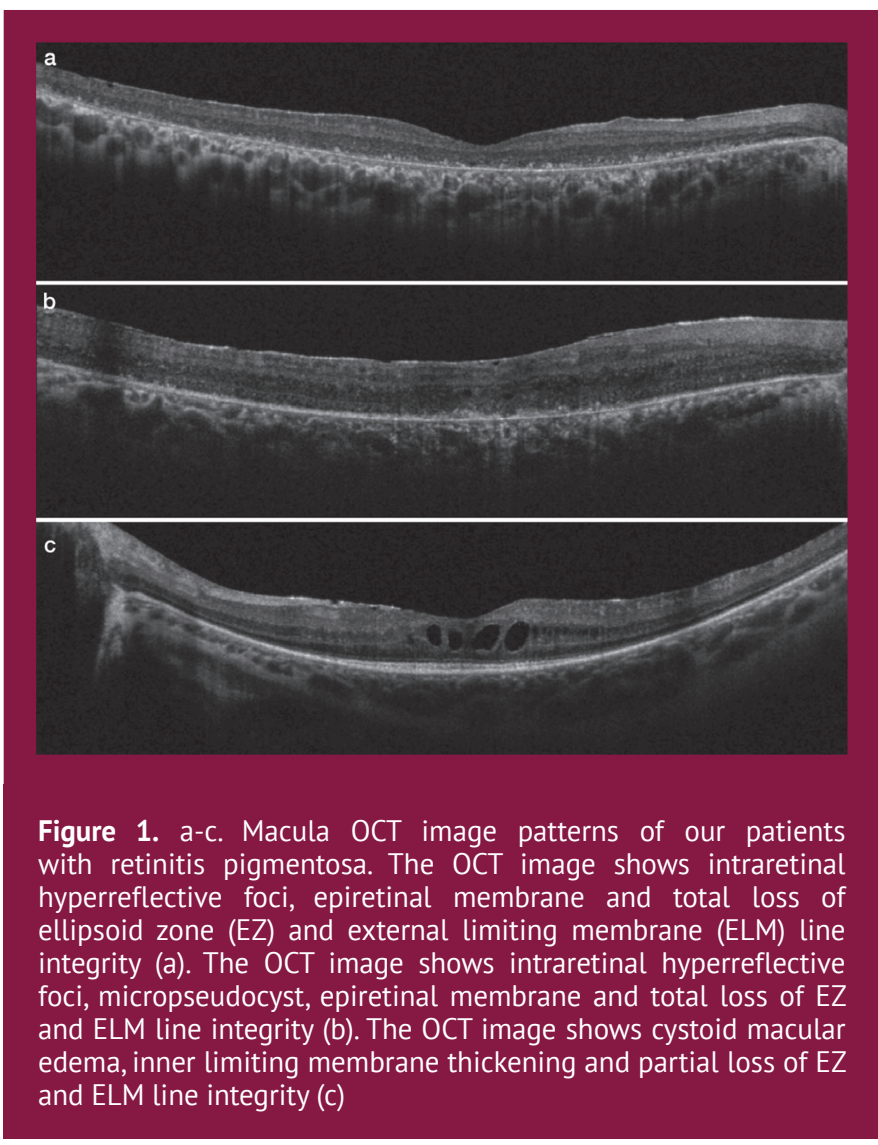

Fundus Autofluorescence Imaging Findings: The distribution of FAF imaging findings of patients with RP is shown in Table 2.FAF images of some of our cases are shown in Figure 2. FAF findings of asymmetry between the two eyes were detected in $44(15 \%)$ of the patients. There was a significant negative correlation between BCVA and loss of AF $(p<0.001)$.

The CMT was $148.7 \pm 62 \mu \mathrm{m}$ in eyes with hyper-AF ring and $129.1 \pm 92 \mu \mathrm{m}$ in eyes without hyper-AF ring $(p<0.001)$. The CMT was $115.4 \pm 87 \mu \mathrm{m}$ in eyes with the absence of AF, $150.9 \pm 83 \mu \mathrm{m}$ in the others $(p<0.001)$. The CMT was $130.5 \pm 74$ um in eyes with abnormal hyper-AF patterns at the macula and $139.7 \pm 97 \mu \mathrm{m}$ in the others $(p=0.254)$. The SCT was $209 \pm 81 \mu \mathrm{m}$ in eyes with hyper-AF ring and $170.2 \pm 88 \mu \mathrm{m}$ in eyes without hyper-AF ring $(p<0.001)$. The SCT was $166 \pm 90$ $\mu \mathrm{m}$ in eyes with the absence of $\mathrm{AF}$ and $189.9 \pm 87 \mu \mathrm{m}$ in the

Table 2. Distribution of fundus autofluorescence imaging findings of retinitis pigmentosa patients

\begin{tabular}{|l|l|}
\hline Fundus autofluorescence imaging findings & Eyes (n) \% \\
\hline Presence of hyper-AF ring & 16928.4 \\
Abnormal hyper-AF patterns at the macula & 27145.3 \\
Absence of AF & 26844.4 \\
Decreased AF at the periphery & 48681.2 \\
\hline AF: Autofluorescence &
\end{tabular}

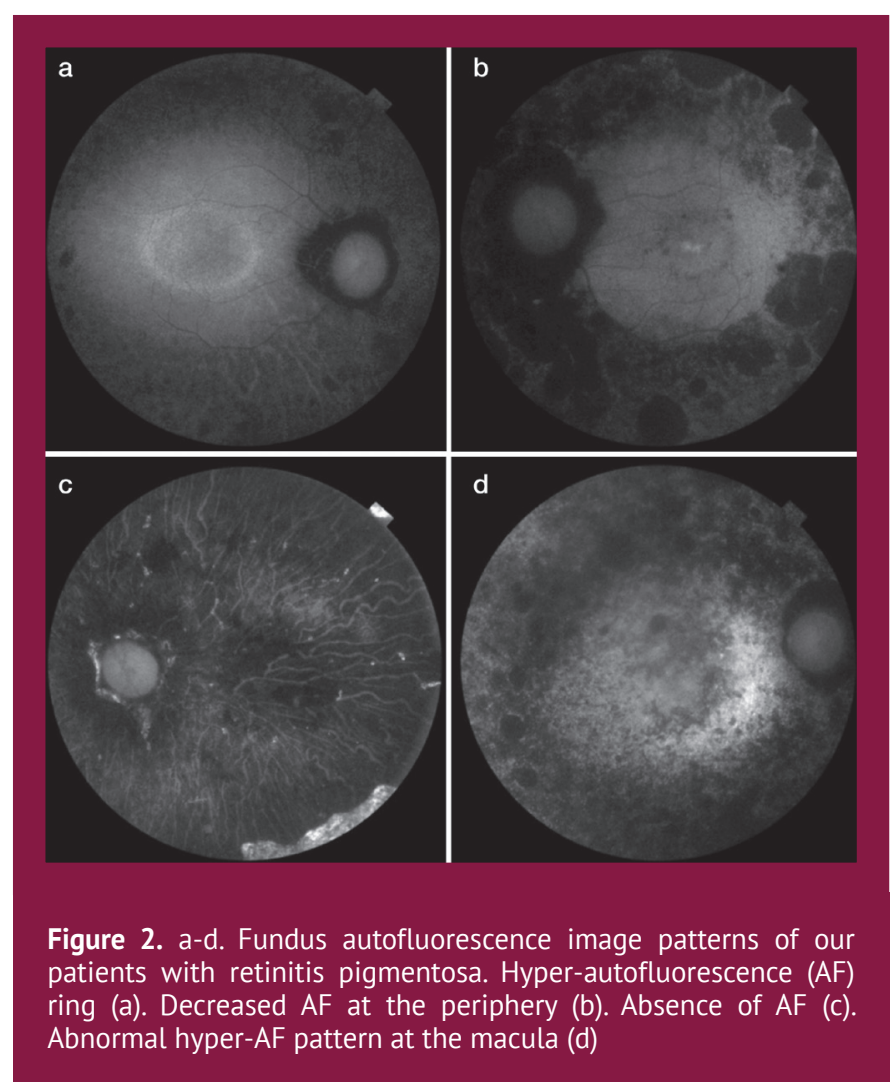


others $(p=0.002)$. The SCT was $187.6 \pm 85$ um in eyes with abnormal hyper-AF patterns at the macula and $176.1 \pm 90$ um in the others $(p=0.079)$. We found a strong correlation between ELM-EZ line integrity and hyper-AF ring or the absence of $A F(p<0.001)$.

\section{Discussion}

To the best of our knowledge, our study includes the ocular findings and multimodal imaging characteristics of the largest number of patients with RP were examined in Turkey. OCT and FAF imaging features of the macula region and the presence of cataract were examined in detail.

The incidence of cataracts (especially PSC) in RP is higher than in the normal population. This condition is thought to develop secondary to inflammation (6). In the study of Lee et al. (7) the incidence of PSC was $25.8 \%$. In our study, $23.6 \%$ of the eyes had cataract surgery and $29.1 \%$ of the eyes had PSC, although the mean age was 43 years. The VA of the eyes with clear lens and pseudophakic was higher than eyes with PSC and nuclear cataract. Therefore, we think that cataract surgery should be performed in patients with RP who have decreased visual acuity due to cataracts.

It has been shown that histopathologic changes in the macula area in RP can be visualized by OCT. These changes revealed by OCT have provided insights into the pathology of $\mathrm{RP}$ as well as for predicting the prognosis of RP (8). Several OCT studies have been published on RP patients to determine whether there is a significant correlation between retinal microstructure and visual function $(9,10,11)$. In our study, the CMT (136.6 \pm 87$)$ was significantly thinner because most of our patients were end-stage RP. As the VA decreased, thinning of the CMT was greater. The EZ line integrity in patients with RP disappeared partially in the early stage and completely in the advanced stage (12). Tamaki et al. (11) reported that CMT and the presence of the EZ line could serve as objective signs for better VA in RP. In our study, deterioration in ELM line integrity was seen in $94.1 \%$ and deterioration of EZ line integrity in $92.6 \%$ of the eyes. Like other studies, we found a strong correlation between ELM-EZ line integrity and VA or CMT. We think that the presence of the ELM-EZ line integrity is associated with better VA and CMT in RP patients.

Patients with RP may develop CME due to breakdown of the blood-retinal barrier, failure (or dysfunction) of the pumping mechanism in the RPE, Müller cell oedema and dysfunction, antiretinal antibodies or vitreous traction (13). Previous studies have reported CME at the rates from 5.5\% to $38 \%$ in RP patients $(14,15,16,17)$. In our study, we detected CME in $6.5 \%$ and MPC in $15.8 \%$ of eyes. No correlation was found between VA and CME or MPC.

Kuroda et al. (12) evaluated intraretinal HF in the OCT of patients with RP. They reported that HF represented macrophages, migrating RPE cells or extracellular lipoproteins. In our study, HF was detected in $43.1 \%$ of the eyes. We found that as the CMT decreased, the ratio of HF presence increased. Therefore, we think that the presence of $\mathrm{HF}$ is a very important OCT finding in patients with RP during the progress of the disease.

It was reported that RP patients have a degenerative vitreous, including collapse of vitreous gel, and posterior vitreous detachment may cause macular complications related to the vitreoretinal interface (18). In the study of Testa et al. (15), ERM in 15.6\%, LMH in 1\% and FTMH in $0.6 \%$ were detected in patients with RP. Triolo et al. (19) found ILMT in $67 \%$, ERM in $27.3 \%$, ILMT and/or ERM in $94.3 \%$ and FTMH in $4.5 \%$ of 176 eyes. In our study, we detected ILMT in $28.2 \%$, ERM in $16.3 \%$, a combination of ILMT and ERM in $3.2 \%$, vitreous bands in $2.4 \%$, LMH in $1.5 \%$ and $\mathrm{FTMH}$ in $0.9 \%$ of 875 eyes. The incidence of vitreomacular interface abnormalities varies among studies. We think that this is due to reasons such as ethnic origin, environmental risk factors, age and having undergone ocular surgery. We also found that vitreomacular interface abnormalities were seen more often in patients who had lower VA, in the elderly and in eyes that underwent cataract surgeries.

Recent studies have evaluated changes in choroidal thickness in patients with RP $(4,20,21)$. Dhoot et al. (4) reported that SCT was significantly reduced in patients with RP, but this did not correlate with VA or CMT. Egawa et al. (20) detected significant correlations between choroidal structures and VA and retinal structures. In our study, thinning of the SCT was found in $77.4 \%$ of the eyes. When patients were older, thinning of the SCT was greater. We found significant correlations between SCT and VA or CMT, but this did not correlate with AL.

FAF results from the accumulation of lipofuscin in RPE cells. Lipofuscin is a by-product of the degradation of photoreceptor outer segments. Hyper-AF indicates abnormal metabolism in RPE cells, a high turnover of photoreceptor outer segments, disrupted phagocytosis, or an intrinsic defect in the ability of the RPE to recycle phagosomes. Hypo-AF indicates RPE atrophy and loss of photoreceptors (22). Murakami et al. (5) reported hyper-AF ring in 59\%, and abnormal central $\mathrm{AF}$ in $18 \%$, and the absence of both patterns was detected in $24 \%$ of patients with RP. The hyper-AF ring is considered to represent the border between functional and dysfunctional retina (22). Lima et al. (23) reported that the diameter of the hyper-AF ring was significantly correlated with the length of the EZ line in patients with RP. In our study, we found hyper-AF ring in $28.4 \%$, abnormal hyper-AF patterns at the macula in $45.3 \%$, the absence of $A F$ in $44.4 \%$ and decreased AF at the periphery in $81.2 \%$ of the eyes. We think that the rate of the presence of hyper-AF ring is less 
in our study than in the other studies because the majority of our cases were end-stage RP patients (77.2\%). We think that hyper-AF ring disappears as the disease progresses, and also remaining macular RPE cells filled with lipofuscin pigment are developing abnormal hyper-AF patterns at the macula. We also found a strong positive correlation between ELM-EZ line integrity and hyper-AF ring, but a strong positive correlation between ELM-EZ line integrity and the absence of AF. While the CMT and SCT were thicker in eyes with the presence of hyper-AF ring, CMT and SCT were thinner in eyes with the absence of AF. VA is significantly lower in eyes with the absence of AF. Therefore, we think that FAF images should be evaluated together with OCT at presentation and during the follow-up period in patients with RP.

Sujirakul et al. (24) followed patients with RP by multimodal imaging for 2 years. They demonstrated an asymmetric structural progression rate between the two eyes. In our study, asymmetry was also observed between the two eyes of the same patient in terms of choroidal and FAF findings. For this reason, we have evaluated both eyes of our patients separately. We think that this should be taken into consideration in subsequent studies.

\section{Study Limitations}

The limitation of this study was the lack of genetic testing for a hereditary transition pattern and electrophysiologic testing. The different patterns we detected in OCT and FAF imaging may be specific to some particular gene defects.

\section{Conclusion}

This is the largest report on clinical and multimodal imaging characteristics of RP in Turkey. In countries with high consanguineous marriages, like Turkey, it is thought that the frequency of seeing issues with time will increase. OCT, FAF and biometry should be used in the examination and followup of patients with RP. We believe that this study will provide a database for describing the patients who can benefit from innovative treatment strategies such as retinal prosthesis and stem cell therapy.

\section{Ethics}

Ethics Committee Approval: This study was approved by the local human research ethics committee, in accordance with the Declaration of Helsinki (number: 1129, date: 24/11/2015).

Informed Consent: Written informed consent was obtained from all participants.

Peer-review: Internally peer-reviewed.

\section{Authorship Contributions}

Surgical and Medical Practices: D.G., S.T.D., H.K., M.K., S.Ü.U., Concept: D.G., S.T.D., Design: D.G., S.T.D., H.K., S.Ü.U., M.K., Data Collection or Processing: H.K., M.K., S.Ü.U., Analysis or Interpretation: D.G., S.T.D., Literature Search: H.K., M.K., S.Ü.U., Writing: S.T.D., D.G.

Conflict of Interest: No conflict of interest was declared by the authors.

Financial Disclosure: The authors declared that this study received no financial support.

\section{References}

1. Verbakel SK, van Huet RAC, Boon CJF, den Hollander Al, Collin RWJ, Klaver CCW, et al. Non-syndromic retinitis pigmentosa. Prog Retin Eye Res. 2018;66:157-186. [Crossref]

2. Mitamura Y, Mitamura-Aizawa S, Nagasawa T, Katome T, Eguchi H, Naito T. Diagnostic imaging in patients with retinitis pigmentosa.J Med Invest. 2012;59:1-11. [Crossref]

3. Garcia-Martin E, Pinilla I, Sancho E, Almarcegui C, Dolz I, RodriguezMena D, et al. Optical coherence tomography in retinitis pigmentosa: reproducibility and capacity to detect macular and retinal nerve fiber layer thickness alterations. Retina. 2012;32:1581-1591. [Crossref]

4. Dhoot DS, Huo S, Yuan A, Xu D, Srivistava S, Ehlers JP, et al. Evaluation of choroidal thickness in retinitis pigmentosa using enhanced depth imaging optical coherence tomography. Br J Ophthalmol. 2013;97:66-69. [Crossref]

5. Murakami T, Akimoto M, Ooto S, Suzuki T, Ikeda H, Kawagoe N, et al. Association between abnormal autofluorescence and photoreceptor disorganization in retinitis pigmentosa. Am J Ophthalmol. 2008;145:687694. [Crossref]

6. Fujiwara K, Ikeda Y, Murakami Y, Funatsu J, Nakatake S, Tachibana T, et al. Risk factors for posterior subcapsular cataract in retinitis pigmentosa. Invest Ophthalmol Vis Sci. 2017;58:2534-2537. [Crossref]

7. Lee SH, Yu HG, Seo JM, Moon SW, Moon JW, Kim SJ, et al. Hereditary and clinical features of retinitis pigmentosa in Koreans. J Korean Med Sci. 2010;25:918-923. [Crossref]

8. Liu G, Liu X, Li H, Du Q, Wang F. Optical coherence tomographic analysis of retina in retinitis pigmentosa patients. Ophthalmic Res 2016;56:111-122. [Crossref]

9. Matsuo T, Morimoto N. Visual acuity and perimacular retinal layers detected by optical coherence tomography in patients with retinitis pigmentosa. Br J Ophthalmol. 2007;91:888-890. [Crossref]

10. Sandberg MA, Brockhurst RJ, Gaudio AR, Berson EL. The association between visual acuity and central retinal thickness in retinitis pigmentosa. Invest Ophthalmol Vis Sci. 2005;46:3349-3354. [Crossref]

11. Tamaki M, Matsuo T. Optical coherence tomographic parameters as objective signs for visual acuity in patients with retinitis pigmentosa, future candidates for retinal prostheses. J Artif Organs 2011;14:140-150. [Crossref]

12. Kuroda M, Hirami Y, Hata M, Mandai M, Takahashi M, Kurimoto Y. Intraretinal hyperreflective foci on spectral-domain optical coherence tomographic images of patients with retinitis pigmentosa. Clin Ophthalmol. 2014;8:435-440. [Crossref]

13. Strong S, Liew G, Michaelides M. Retinitis pigmentosa associated cystoid macular oedema: pathogenesis and avenues of intervention. $\mathrm{Br} J$ Ophthalmol. 2017;101:31-37. [Crossref]

14. Hagiwara A, Yamamoto S, Ogata K, Sugawara T, Hiramatsu A, Shibata $M$, et al. Macular abnormalities in patients with retinitis pigmentosa: 
prevalence on OCT examination and outcomes of vitreoretinal surgery. Acta Ophthalmol. 2011;89:122-125. [Crossref]

15. Testa F, Rossi S, Colucci R, Gallo B, Di lorio V, della Corte M, et al. Macular abnormalities in Italian patients with retinitis pigmentosa. $\mathrm{Br}$ J Ophthalmol. 2014;98:946-950. [Crossref]

16. Kim YJ, Joe SG, Lee DH, Lee JY, Kim JG, Yoon YH. Correlations between spectral-domain OCT measurements and visual acuity in cystoid macular edema associated with retinitis pigmentosa Invest Ophthalmol Vis Sci. 2013;54:1303-1309. [Crossref]

17. Hajali M, Fishman GA, Anderson RJ. The prevalence of cystoid macular oedema in retinitis pigmentosa patients determined by optical coherence tomography. Br J Ophthalmol. 2008;92:1065-1068. [Crossref]

18. Jin ZB, Gan DK, Xu GZ, Nao-I N. Macular hole formation in patients with retinitis pigmentosa and prognosis of pars plana vitrectomy. Retina. 2008;28:610-614. [Crossref]

19. Triolo G, Pierro L, Parodi MB, De Benedetto U, Gagliardi M, Manitto MP, et al. Spectral domain optical coherence tomography findings in patients with retinitis pigmentosa. Ophthalmic Res. 2013;50:160-164. [Crossref]
20. Egawa M, Mitamura Y, Niki M, Sano H, Miura G, Chiba A, et al. Correlations between choroidal structures and visual functions in eyes with retinitis pigmentosa. Retina. 2019;39:2399-2409. [Crossref]

21. Ayton LN, Guymer RH, Luu CD. Choroidal thickness profiles in retinitis pigmentosa. Clin Exp Ophthalmol. 2013;41:396-403. [Crossref]

22. Popović P,Jarc-Vidmar M, Hawlina M.Abnormal fundus autofluorescence in relation to retinal function in patients with retinitis pigmentosa. Graefes Arch Clin Exp Ophthalmol. 2005;243:1018-1027. [Crossref]

23. Lima LH, Cella W, Greenstein VC, Wang NK, Busuioc M, Smith RT, et al. Structural assessment of hyperautofluorescent ring in patients with retinitis pigmentosa. Retina. 2009;29:1025-1031. [Crossref]

24. Sujirakul T, Lin MK, Duong J, Wei Y, Lopez-Pintado S, Tsang SH. Multimodal imaging of central retinal disease progression in a 2-year mean follow-up of retinitis pigmentosa. Am J Ophthalmol. 2015;160:786-798. [Crossref] 